\title{
Magnitude and determinants of nonadherence and nonreadiness to highly active antiretroviral therapy among people living with HIV/AIDS in Northwest Ethiopia: a cross - sectional study
}

Belay Tessema ${ }^{1,5,6^{*}}$, Fantahun Biadglegne ${ }^{2}$, Andargachew Mulu ${ }^{3}$, Assefa Getachew ${ }^{4}$, Frank Emmrich ${ }^{5,7}$, Ulrich Sack ${ }^{5,7}$

\begin{abstract}
Background: Adequate antiretroviral drug potency is essential for obtaining therapeutic benefit, however, the behavioral aspects of proper adherence and readiness to medication, often determine therapeutic outcome. Therefore, this study aimed to assess the level and determinants of nonadherence and nonreadiness to highly active antiretroviral therapy (HAART) among people living with HIV/AIDS (PLWHA) at Gondar University Teaching Hospital and Felege Hiwot Hospital in Northwest Ethiopia.
\end{abstract}

Methods: A cross-sectional study was conducted between July and September 2008 using structured intervieweradministered questionnaire. All consecutive adult outpatients who were receiving antiretroviral treatment for at least three months, seen at both hospitals during the study period and able to give informed consent were included in the study. Multivariate logistic regression was used to determine factors associated with nonadherence and nonreadiness.

Results: A total of 504 study subjects were included in this study. The prevalence rates of nonadherence and nonreadiness to HAART were 87 (17.3\%) and 70 (13.9\%) respectively. Multivariate logistic regression analysis revealed that medication adverse effects, nonreadiness to HAART, contact with psychiatric care service and having no goal had statistically significant association with nonadherence. Moreover, unwillingness to disclose HIV status was significantly associated with nonreadiness to HAART.

Conclusions: In this study the level of nonadherence and nonreadiness to HAART seems to be encouraging. Several factors associated with nonadherance and nonreadiness to HAART were identified. Efforts to minimize nonadherence and nonreadiness to HAART should be integrated in to regular clinical follow up of patients.

\section{Introduction}

HIV/AIDS is the fourth most common cause of death in the world [1] and is estimated to have killed 3.1 million individuals and infected 4.9 million persons in 2005 alone. The number of people infected by HIV is steadily rising and sub-Saharan Africa is the most affected region in the world [2]. Ethiopia has the fifth largest population of HIVinfected individuals living in Africa, which accounts approximately $4 \%$ of the world's HIV/AIDS cases [3].

\footnotetext{
* Correspondence: bt1488@yahoo.com

'Department of Medical Laboratory Technology, College of Medicine and Health Sciences, University of Gondar, Gondar, Ethiopia
}

Highly Active Antiretroviral Treatment (HAART) has dramatically reduced mortality and morbidity due to HIV [4,5]. It is effective because it reduces HIV replication and hence allows the regeneration of CD4+ T-lymphocyte mediated immune responses [6,7]. It cannot, however, totally eradicate HIV $[8,9]$ and hence prolonged viral suppression is essential for long-term efficacy of HAART $[10,11]$.

Prolonged viral suppression is only achievable if the virus does not get the chance to replicate and develop drug-resistant HIV variants [12]. The virus has the chance to replicate not only if the patient is untreated 
[13] but also if the viral replication is not completely inhibited by the treatment (i.e. due to sub-optimal drug exposure) [14]. When replication occurs during treatment, this leads to the development of genetic variation, which in turn leads to the emergence of variants that might be resistant to antiretroviral treatment [12].

Despite the high prevalence of HIV/AIDS in Africa including Ethiopia, the HAART coverage is extremely low due to limited resources, but in these days WHO as well as different countries are interested to intensify the HAART activities and expand the program as preventive strategy for HIV epidemic and AIDS patient care[15].

Ethiopia has been started provision of HAART for the people living with HIV/AIDS since August 2003. However, by the end of June 2008, there were only 110,611 patients (75\%) who were alive and on HAART out of the 150,136 patients who had been started on HAART since 2003 [16]. This indicates the need for an intervention to reduce the drop-out rate due to either death or loss to follow-up.

One of the main factors contributing to sub-optimal drug levels and resistance is non-adherence to treatment $[17,18]$. It has been reported that the patient needs to take a minimum of $95 \%$ of prescribed antiretroviral doses in order to avoid resistance development. Patients taking $95 \%$ or more of their doses only had a documented virologic failure (i.e. over 400 virus copies $/ \mathrm{mL}$ in blood) in $22 \%$ of the cases compared to $80 \%$ of the patients taking less than $80 \%$ of their doses [17].

Patient's readiness to antiretroviral therapy means put the patient himself/herself feels ready to initiate, take responsibility for, and to maintain (including being adherent to) a prescribed treatment [19]. Readiness for treatment can be assessed prior to treatment initiation and hence timely measures can be taken before initiation of therapy, sometimes postponement of treatment may be preferable in order to motivate and increase the degree of readiness, and hence, hopefully, increase the success rate of the treatment [20].

Assessment of patient adherence and readiness to treatment are good opportunities to enhance patient understanding of medication regimen, to identify potential obstacles to taking medication and trusting relationship between patients and health care providers, and ultimately to prevent virologic break through [21]. Therefore, this study aimed to assess the level and determinants of nonadherence and nonreadiness to HAART among PLWHA at Gondar University Teaching Hospital and Felege Hiwot Hospital in Northwest Ethiopia.

\section{Methods}

\section{Study design, area, and period}

A cross-sectional study was conducted between July and September 2008 at Gondar University Teaching Hospital and Felege Hiwot Hospital in Northwest Ethiopia. These hospitals are tertiary level teaching hospitals that each hospital provides health service to over five million inhabitants in Northwest Ethiopia, located $727 \mathrm{Km}$ and $540 \mathrm{Km}$ away from the capital city, Addis Ababa respectively.

\section{Study subjects}

All consecutive adult outpatients who were receiving antiretroviral treatment at least for three months, seen at both clinics during the study period and able to give informed consent were included in the study.

\section{Data collection}

Data was collected using structured interviewer-administered questionnaires which include the following variables: socio-demographic characteristics, knowledge of patients towards treatment and health care system, patient attitude towards health care provider and program and patients self-report to treatment adherence and readiness. Prior to data collection, training to nurses (interviewers) about the objectives of the study and methods of interviewing was given and the English version questionnaire was translated to the local language (Amharic). Institutional ethical clearance was obtained from the research and publication committee of Gondar University.

\section{Assessments}

\section{Adherence}

Respondents were asked whether they had missed any doses the day prior to completing the questionnaire, and how often doses were missed in general (ranging from every day to never). Respondents, who were reported that they had not forgotten a dose the day prior to the completion of the questionnaire and those responded that they never forget doses were categorized as adherent. This strict definition of adherence was chosen, since the respondents providing us with these answers would theoretically reach an adherence level of at least 95\% [17].

\section{Readiness}

Patients' readiness to HAART was determined based on the five indicators of readiness [19]: These indicators are: Changing attitudes towards HIV medication, finding the right health care provider, creating the right support system, getting control over life and having goals. Changing attitudes towards HIV medication was assessed by asking the patients if they thought that their present treatment would prevent them from becoming ill as a result of their HIV infection. Finding the right health care provider was assessed by asking the patients how they perceive their contacts with health care staffs. Creating the right support system was measured by two-question assessment of social support for taking medicine. First patients were asked whether they had friends or relatives to talk about their treatment, second patients were asked whether they had 
Table 1 Socio-demographic characteristics of PLWHA, Felege Hiwot Hospital and Gondar University Teaching Hospital, Northwest Ethiopia, 2008

\begin{tabular}{|c|c|c|c|c|c|c|}
\hline \multirow[t]{2}{*}{ Socio demographic characteristics } & \multicolumn{2}{|c|}{ Felege Hiwot Hospital } & \multicolumn{2}{|c|}{ Gondar University Hospital } & \multicolumn{2}{|c|}{ Total } \\
\hline & Number & Percent & Number & Percent & Number & Percent \\
\hline \multicolumn{7}{|l|}{ Sex } \\
\hline Male & 98 & 38.9 & 96 & 38.1 & 194 & 38.5 \\
\hline Female & 154 & 61.1 & 156 & 61.9 & 310 & 61.5 \\
\hline \multicolumn{7}{|l|}{ Age group (Years) } \\
\hline $18-24$ & 11 & 4.4 & 28 & 11.1 & 39 & 7.7 \\
\hline $25-34$ & 95 & 37.7 & 102 & 40.5 & 197 & 39.1 \\
\hline $35-44$ & 109 & 43.3 & 83 & 32.9 & 192 & 38.1 \\
\hline $45-54$ & 28 & 11.1 & 33 & 13.1 & 61 & 12.1 \\
\hline$\geq 55$ & 9 & 3.6 & 6 & 2.4 & 15 & 3.0 \\
\hline \multicolumn{7}{|l|}{ Address } \\
\hline Urban & 217 & 86.1 & 235 & 93.3 & 452 & 89.7 \\
\hline Rural & 35 & 13.9 & 17 & 6.7 & 52 & 10.3 \\
\hline \multicolumn{7}{|l|}{ Educational status } \\
\hline Illiterate & 70 & 27.8 & 68 & 27.0 & 138 & 27.4 \\
\hline Read and write & 20 & 7.9 & 21 & 8.3 & 41 & 8.1 \\
\hline Primary school & 77 & 30.6 & 44 & 17.5 & 121 & 24.0 \\
\hline Secondary school & 65 & 25.8 & 92 & 36.5 & 157 & 31.2 \\
\hline Diploma and above & 20 & 7.9 & 27 & 10.7 & 47 & 9.3 \\
\hline \multicolumn{7}{|l|}{ Marital status } \\
\hline Single & 27 & 10.7 & 47 & 18.7 & 74 & 14.7 \\
\hline Married & 113 & 44.8 & 111 & 44.0 & 224 & 44.4 \\
\hline Divorced & 47 & 18.7 & 52 & 20.6 & 99 & 19.6 \\
\hline Widowed & 65 & 25.8 & 42 & 16.7 & 107 & 21.2 \\
\hline \multicolumn{7}{|l|}{ Monthly income (USD) } \\
\hline$<45.25$ & 113 & 44.8 & 141 & 56.0 & 254 & 50.4 \\
\hline $45.25-90.41$ & 3 & 1.2 & 6 & 2.4 & 9 & 1.8 \\
\hline$>90.41$ & 79 & 31.3 & 53 & 21.0 & 132 & 26.2 \\
\hline Unstated & 57 & 22.6 & 52 & 20.6 & 109 & 21.6 \\
\hline \multicolumn{7}{|l|}{ Religion } \\
\hline Christian & 229 & 90.9 & 242 & 96.0 & 471 & 93.5 \\
\hline Muslim & 23 & 9.1 & 10 & 4.0 & 33 & 6.5 \\
\hline \multicolumn{7}{|l|}{ Ethnicity } \\
\hline Amhara & 246 & 97.6 & 242 & 96.0 & 488 & 96.8 \\
\hline Tigre & 6 & 2.4 & 3 & 1.2 & 9 & 1.8 \\
\hline Oromo & - & - & 2 & 0.8 & 2 & 0.4 \\
\hline Others & - & - & 5 & 2.0 & 5 & 1.0 \\
\hline \multicolumn{7}{|l|}{ Occupation } \\
\hline Merchant & 35 & 13.9 & 38 & 15.1 & 73 & 14.5 \\
\hline Farmer & 18 & 7.1 & 16 & 6.3 & 34 & 6.7 \\
\hline Student & 5 & 2.0 & 12 & 4.8 & 17 & 3.4 \\
\hline Government employee & 48 & 19.0 & 42 & 16.7 & 90 & 17.9 \\
\hline Daily labourer & 56 & 22.2 & 58 & 23.0 & 114 & 22.6 \\
\hline NGO employee & 25 & 9.9 & 25 & 9.9 & 50 & 9.9 \\
\hline Others & 65 & 25.8 & 61 & 24.2 & 126 & 25.0 \\
\hline \multicolumn{7}{|l|}{ Substance use } \\
\hline Yes & 28 & 11.1 & 8 & 3.2 & 36 & 7.1 \\
\hline No & 224 & 88.9 & 244 & 96.8 & 468 & 92.9 \\
\hline
\end{tabular}

$\mathrm{NGO}=$ Non governmental organization 
friends or relatives who reminded them to take their medicine. Patients answering no to both of these items were considered as lacking social support. Getting control over life was assessed by asking whether the patient has a special system to remember the medication. The last indicator, having goals was assessed by asking whether the patient is developing and maintaining specific goals when living with HIV. Goals could be relatively long-term, intermediate, or even very short-term. What's important is maintaining incentives to live, to feel that there's something left to accomplish or to learn or to contribute to the world. Respondents, who presented the aforementioned five indicators of readiness, were categorized as ready to HAART.

\section{Statistical analysis}

Data was coded, cleared, entered and analysed using SPSS statistical software version 13. Different variables

Table 2 Treatment, psychosocial and health service related variables of PLWHA, Felege Hiwot Hospital and Gondar University Teaching Hospital, Northwest Ethiopia, 2008

\begin{tabular}{|c|c|c|c|c|c|c|}
\hline \multirow[t]{2}{*}{ Clinical and Psychosocial variables } & \multicolumn{2}{|c|}{ Felege Hiwot Hospital } & \multicolumn{2}{|c|}{ Gondar University Hospital } & \multicolumn{2}{|c|}{ Total } \\
\hline & Number & Percent & Number & Percent & Number & Percent \\
\hline \multicolumn{7}{|l|}{ Duration of treatment (months) } \\
\hline $3-6$ & 34 & 13.5 & 69 & 27.4 & 103 & 20.4 \\
\hline $7-12$ & 47 & 18.7 & 68 & 27.0 & 115 & 22.8 \\
\hline $13-18$ & 31 & 12.3 & 22 & 8.7 & 53 & 10.5 \\
\hline $19-24$ & 47 & 18.7 & 49 & 19.4 & 96 & 19.0 \\
\hline$\geq 25$ & 93 & 36.9 & 44 & 17.5 & 137 & 27.2 \\
\hline \multicolumn{7}{|l|}{ HIV status disclosure } \\
\hline Yes & 230 & 91.3 & 200 & 79.4 & 430 & 85.3 \\
\hline No & 22 & 8.7 & 52 & 20.6 & 74 & 14.7 \\
\hline \multicolumn{7}{|l|}{ Treatment side effects } \\
\hline Yes & 61 & 24.2 & 138 & 54.8 & 199 & 39.5 \\
\hline No & 191 & 75.8 & 114 & 45.2 & 305 & 60.5 \\
\hline \multicolumn{7}{|l|}{ Clinical follow up } \\
\hline Monthly & 13 & 5.2 & 95 & 37.7 & 108 & 21.4 \\
\hline Every two months & 8 & 3.2 & 91 & 36.1 & 99 & 19.6 \\
\hline Every three months & 91 & 36.1 & 44 & 17.5 & 135 & 26.8 \\
\hline Variable & 140 & 55.6 & 22 & 8.7 & 162 & 32.1 \\
\hline \multicolumn{7}{|l|}{ Perceived access to Pharmacy } \\
\hline Yes & 248 & 98.4 & 205 & 81.3 & 453 & 89.9 \\
\hline No & - & - & 17 & 6.7 & 17 & 3.4 \\
\hline Not sure & 4 & 1.6 & 30 & 11.9 & 34 & 6.7 \\
\hline \multicolumn{7}{|l|}{ Belief on HAART benefits } \\
\hline Yes & 250 & 99.2 & 245 & 97.2 & 495 & 98.2 \\
\hline No & - & - & 5 & 2.0 & 5 & 1.0 \\
\hline I doubt & 2 & 0.8 & 2 & 0.8 & 4 & 0.8 \\
\hline \multicolumn{7}{|l|}{ Contact with psychiatric care services } \\
\hline Yes & 16 & 6.3 & 43 & 17.1 & 59 & 11.7 \\
\hline No & 236 & 93.7 & 209 & 82.9 & 445 & 88.3 \\
\hline \multicolumn{7}{|l|}{ Perceived satisfaction with HCP } \\
\hline Yes & 242 & 96.0 & 234 & 92.9 & 476 & 94.4 \\
\hline No & - & - & 13 & 5.2 & 13 & 2.6 \\
\hline Not sure & 10 & 4.0 & 5 & 2.0 & 15 & 3.0 \\
\hline \multicolumn{7}{|l|}{ Having goals } \\
\hline Yes & 249 & 98.8 & 236 & 93.7 & 485 & 96.2 \\
\hline No & 3 & 1.2 & 16 & 6.3 & 19 & 3.8 \\
\hline \multicolumn{7}{|l|}{ Comfortable when taking HAART in front of others } \\
\hline Yes & 124 & 49.2 & 125 & 49.6 & 249 & 49.4 \\
\hline No & 128 & 50.8 & 127 & 50.4 & 255 & 50.6 \\
\hline
\end{tabular}

$\mathrm{HCP}=$ Health Care Providers 
were described and characterized by frequency distribution. Association between the dependent and independent variables was analyzed using chi- square test and multivariate logistic regression. In all cases p-value of less than 0.05 was taken to indicate level of statistical significance.

\section{Results}

\section{Socio-demographic characteristics}

A total of 504 study subjects (252 from each hospital) were included in this study. Of these, 310 (61.5\%) respondents were females and 194 (38.5\%) were males with the mean (SD) age of 35.3 (8.9) years. Most of the study subjects, 452 (89.7\%) were urban resident, 488 (96.8\%) were Amhara by ethnicity and 471 (93.5\%) were Christian by religion. Large number of the respondents, $138(27.4 \%)$ were illiterate, 107 (21.2\%) were widowed, $114(22.6 \%)$ were daily labourers and 254 (50.4\%) had household income below 45.25 USD per month. Moreover, thirty six (7.1\%) study subjects were reported active substance use (alcohol, Khat and/or cigarette) (Table 1).

\section{Treatment, clinical, psychosocial and health service} related variables

The study subjects were on HAART for a mean and median duration of 18.9 and 16.5 months respectively.
Of all study subjects, 430 (85.3\%) had disclosed their sero-status (to family members, friends and/or neighbors). Four hundred ninety five (98.2\%) respondents thought that HAART had benefited them by improving their quality of life or improving their symptoms. One hundred ninety nine (39.5\%) had an adverse reaction to HAART like skin rash, itching, nausea, and/or vomiting since starting HAART. More than half, 255 (50.6\%) participants had discomfort when taking their drugs in front of others, and most of the respondents, 476 (94.4\%) were satisfied with the health care providers service. Majority of respondents, $453(89.9 \%)$ had access to pharmacy at any time and $108(21.4 \%)$ patients were visiting their doctors monthly. Moreover, 59 (11.7\%) respondents reported contact with psychiatric care services and 485 (96.2\%) were having goals (Table 2).

\section{Self reported nonadherence and nonreadiness to HAART among the study subjects}

The level of nonadherence and nonreadiness to HAART were $87(17.3 \%)$ and $70(13.9 \%)$ respectively. The main reasons for nonadherence are drug side effects 27 (31.0\%) and other health problems 19 (21.8\%). On the other hand, the major reasons for nonreadiness to HAART are anxiety $31(44.3 \%)$ and hopelessness 19 (27.1\%). Of all study subjects, 419 (83.1\%) were highly

Table 3 Self reported nonadherence and nonreadiness to HAART, Felege Hiwot Hospital and Gondar University Teaching Hospital, Northwest Ethiopia, 2008

\begin{tabular}{|c|c|c|c|c|c|c|}
\hline \multirow[t]{2}{*}{ Variables } & \multicolumn{2}{|c|}{ Felege Hiwot Hospital } & \multicolumn{2}{|c|}{ Gondar University Hospital } & \multicolumn{2}{|c|}{ Total } \\
\hline & Number & Percent & Number & Percent & Number & Percent \\
\hline \multicolumn{7}{|l|}{ Adherence status } \\
\hline Adherent & 231 & 91.7 & 186 & 73.8 & 417 & 82.7 \\
\hline Nonadherent & 21 & 8.3 & 66 & 26.2 & 87 & 17.3 \\
\hline \multicolumn{7}{|l|}{ Readiness status } \\
\hline Ready & 242 & 96.0 & 192 & 76.2 & 434 & 86.1 \\
\hline Not ready & 10 & 4.0 & 60 & 23.8 & 70 & 13.9 \\
\hline \multicolumn{7}{|l|}{ Motivation to take HAART } \\
\hline Not at all motivated & 1 & 0.4 & 10 & 4.0 & 11 & 2.2 \\
\hline Partially motivated & 18 & 7.1 & 56 & 22.2 & 74 & 14.7 \\
\hline Highly motivated & 233 & 92.5 & 186 & 73.8 & 419 & 83.1 \\
\hline \multicolumn{7}{|l|}{ Reasons for nonadherence } \\
\hline Drug side effects & 4 & 19.1 & 23 & 34.9 & 27 & 31.0 \\
\hline Other health problems & 6 & 28.6 & 13 & 19.7 & 19 & 21.8 \\
\hline Getting a relief & 1 & 4.8 & 4 & 6.1 & 5 & 5.75 \\
\hline Drug scarcity & 2 & 9.5 & 2 & 3.0 & 4 & 4.6 \\
\hline Others & 8 & 38.1 & 24 & 36.4 & 32 & 36.8 \\
\hline \multicolumn{7}{|c|}{ Reasons for nonreadiness to HAART } \\
\hline Anxiety & - & - & 31 & 51.7 & 31 & 44.3 \\
\hline Hopelessness & 8 & 80.0 & 11 & 18.3 & 19 & 27.1 \\
\hline Confusion & - & - & 14 & 23.3 & 14 & 20.0 \\
\hline Denial & 2 & 10.0 & 1 & 1.7 & 3 & 4.3 \\
\hline Others & - & - & 3 & 5.0 & 3 & 4.3 \\
\hline
\end{tabular}


Table 4 Association of variables with nonadherence to HAART, Felege Hiwot Hospital and Gondar University Teaching Hospital, Northwest Ethiopia, 2008

\begin{tabular}{|c|c|c|c|c|c|c|}
\hline \multirow[t]{2}{*}{ Determinants } & \multicolumn{2}{|c|}{ Adherence status } & \multirow{2}{*}{$\begin{array}{c}\text { Adjusted } \\
\text { OR }^{* *}\end{array}$} & \multicolumn{2}{|c|}{$95 \% \mathrm{Cl}$} & \multirow[t]{2}{*}{ P-Values } \\
\hline & $\begin{array}{c}\text { Nonadherent } \\
\mathrm{N}(\%)\end{array}$ & $\begin{array}{l}\text { Adherent } \\
\mathrm{N}(\%)\end{array}$ & & Lower & Upper & \\
\hline \multicolumn{7}{|c|}{ Treatment side effects } \\
\hline $\mathrm{No}^{*}$ & $34(39.1)$ & $271(65.0)$ & 1.0 & - & - & - \\
\hline Yes & $53(60.9)$ & $146(35.0)$ & 1.4 & 0.8 & 2.5 & 0.04 \\
\hline \multicolumn{7}{|c|}{ Readiness to HAART } \\
\hline Ready* & $46(52.9)$ & $388(93.0)$ & 1.0 & - & - & - \\
\hline Not ready & $41(47.1)$ & $29(7.0)$ & 8.9 & 4.8 & 16.7 & $<0.001$ \\
\hline \multicolumn{7}{|c|}{ Contact with psychiatric care services } \\
\hline $\mathrm{No}^{*}$ & $69(79.3)$ & $376(90.2)$ & 1.0 & - & - & - \\
\hline Yes & $18(20.7)$ & $41(9.8)$ & 2.2 & 1.1 & 4.5 & 0.02 \\
\hline \multicolumn{7}{|l|}{ Having goals } \\
\hline Yes* $^{*}$ & $76(87.4)$ & 409 (98.1) & 1.0 & - & - & - \\
\hline No & $11(12.6)$ & $8(1.9)$ & 3.5 & 1.1 & 10.8 & 0.03 \\
\hline
\end{tabular}

$\mathrm{N}=$ Number, $\mathrm{OR}=$ Odds ratio, $\mathrm{Cl}=$ Confidence interval; ${ }^{*}=$ Reference Category; ${ }^{* *}=$ All the variables in the table are included in the model

motivated to take HAART, $74(14.7 \%)$ were partially motivated and $11(2.2 \%)$ respondents were not at all motivated to take HAART (Table 3).

\section{Determinants of patients' nonadherence and} nonreadiness to HAART

Results of multivariate logistic regression analyses showed that treatment adverse effects $(\mathrm{P}=0.04 ; \mathrm{OR}=$ 1.4; $95 \% \mathrm{CI}=0.8-2.5)$, nonreadiness to HAART $(\mathrm{P}<$ $0.001 ; \mathrm{OR}=8.9 ; 95 \% \mathrm{CI}=4.8-16.7)$, contact with psychiatric care service $(\mathrm{P}=0.02$; $\mathrm{OR}=2.2 ; 95 \% \mathrm{CI}=1.1$ 4.5 ) and having no goal $(\mathrm{P}=0.03$; $\mathrm{OR}=3.5$; $95 \% \mathrm{CI}=$ 1.1 - 10.8) had statistically significant association with nonadherence (Table 4). Moreover, unwillingness to disclose HIV status $(\mathrm{P}=0.04 ; \mathrm{OR}=1.9 ; 95 \% \mathrm{CI}=1.1$ 3.5) was significantly associated with nonreadiness to antiretroviral therapy (Table 5).

\section{Discussion}

The prevalence of nonadherence and nonreadiness to HAART and their determinants among patients attending the antiretroviral clinics in Gondar and Felege Hiwot Hospitals in Northwest Ethiopia were the focuses of this study. Of all study subjects, 87 (17.3\%) respondents had less than $95 \%$ adherence and 70 (13.9\%) of the respondents had not been ready to HAART. The level of nonadherence in this study was comparable with those reported in Addis Ababa (capital city of Ethiopia) where adherence rates were $81.2 \%$ [22] and $82.8 \%$ [23], but it was lower than in most developed countries, where adherence rates ranged from $50 \%$ to $70 \%[24,25]$. The low level of nonadherence in our study compared to in most developed countries might be due to the infancy stage of HAART program in the study areas.

Table 5 Association of variables with nonreadiness to HAART, Felege Hiwot Hospital and Gondar University Teaching Hospital, Northwest Ethiopia, 2008

\begin{tabular}{|c|c|c|c|c|c|c|}
\hline \multirow[t]{2}{*}{ Variables } & \multicolumn{2}{|c|}{ Readiness status } & \multirow{2}{*}{$\begin{array}{c}\text { Adjusted } \\
\text { OR }^{* *}\end{array}$} & \multicolumn{2}{|c|}{$95 \% \mathrm{Cl}$} & \multirow[t]{2}{*}{ P-Values } \\
\hline & $\begin{array}{c}\text { Not ready } \\
\text { N (\%) }\end{array}$ & $\begin{array}{l}\text { Ready } \\
\text { N (\%) }\end{array}$ & & Lower & Upper & \\
\hline \multicolumn{7}{|l|}{ Sex } \\
\hline Male* & $25(35.7)$ & 169 (38.9) & 1.0 & - & - & - \\
\hline Female & $45(64.3)$ & $265(61.1)$ & 1.1 & 0.7 & 1.9 & 0.636 \\
\hline \multicolumn{7}{|c|}{ HIV status disclosure } \\
\hline Yes $^{*}$ & 55 (78.6) & $375(86.4)$ & 1.0 & - & - & - \\
\hline No & $15(21.4)$ & $58(13.6)$ & 1.9 & 1.1 & 3.5 & 0.04 \\
\hline \multicolumn{7}{|c|}{ Contact with psychiatric care services } \\
\hline $\mathrm{No}^{*}$ & $58(82.9)$ & $387(89.2)$ & 1.0 & - & - & - \\
\hline Yes & $12(17.1)$ & $47(10.8)$ & 1.8 & 0.9 & 3.6 & 0.101 \\
\hline
\end{tabular}

$\mathrm{N}=$ Number; $\mathrm{OR}=$ Odds ratio; $\mathrm{Cl}=$ Confidence interval; ${ }^{*}=$ Reference category; ${ }^{*}=$ All the variables in the table are included in the model 
The multivariate logistic regression analyses showed that medication adverse effects had statistically significant association with nonadherence to antiretroviral therapy. This is in agreement with the findings of other studies conducted in Brazil, Senegal and Addis Ababa $[22,26,27]$. Efforts to improve the level of adherence should be made by letting patients know at the start of the treatment which side effects are possible with a given regimen, monitoring for such effects and provide treatment for adverse effects even beginning with the first prescription.

Although there are few published studies, and they have used different methods to assess readiness, a significant association between the level of readiness and the level of adherence has been observed [28]. This observation is consistent with the finding of the current study. Contact with psychiatric care service also showed significant association with nonadherence to HAART. This is in agreement with studies conducted elsewhere [29-31]. This significant association might be due to the fact that most people with HIV, at some time in the course of their illness, experience a psychiatric disorder [32,33], and AIDS related dementia (AIDS Dementia Complex ADC) characterized by abnormalities in cognitive as well as motor function [34].

Having long-term plans and goals, using time wisely and having a meaningful life are characteristics of patients who have fewer adherence difficulties [30,35]. This is also reflected in our study, that having no goal had significant association with nonadherence. Moreover, in the present study, unwillingness to disclose HIV status was significantly associated with nonreadiness to antiretroviral therapy (Table 5). This finding is consistent with the finding of other study where disclosure [36] is considered as barrier that prevent patients from wanting to start and to adhere to HAART.

Our study has the following limitations. First, we measured adherence and readiness of patients to HAART by patient self - report, which may be subject to recall bias and overestimate adherence and readiness. Nevertheless, many other studies document that well collected self report data clearly correlates with virologic changes and is more practical in most settings $[37,38]$. Second, we were unable to relate the obtained adherence rate to viral loads, CD4+ T-cell counts and clinical progression due to financial and logistical constraints. Comparison of reported adherence levels with viral loads, CD4+ Tcell counts and clinical progression would be beneficial in providing a more comprehensive view of adherence to HAART.

\section{Conclusions}

In this study the level of nonadherence and nonreadiness to HAART seems to be encouraging. Medication adverse effects, nonreadiness to HAART, contact with psychiatric care service and having no goal were significant barriers to treatment adherence. Moreover, unwillingness to disclose HIV status was a significant factor for nonreadiness to HAART. Therefore, efforts to minimize nonadherence and nonreadiness to HAART should address these barriers among others, and should be integrated in to regular clinical follow up of patients. Furthermore, continuous measurement of patients' non adherence and nonreadiness, to identify when interventions are required, seems to be an approach worth further investigation.

\section{Acknowledgements}

This study was carried out with the financial support obtained from HIV/ AIDS Prevention and Control Secretariat Office of Amhara National Regional State. Our appreciation goes to the study participants, the data collectors and the staffs of Gondar University Teaching Hospital and Felege Hiwot Hospital ART clinics.

\section{Author details}

'Department of Medical Laboratory Technology, College of Medicine and Health Sciences, University of Gondar, Gondar, Ethiopia. ${ }^{2}$ Department of Microbiology, Immunology and Parasitology, College of Medicine and Health Sciences, University of Bahir Dar, Bahir Dar, Ethiopia. ${ }^{3}$ Department of Microbiology and Parasitology, College of Medicine and Health Sciences, University of Gondar, Gondar, Ethiopia. ${ }^{4}$ Department of Radiology, College of Medicine and Health Sciences, University of Gondar, Gondar, Ethiopia. ${ }^{5}$ Institute of Clinical Immunology, Faculty of Medicine, University of Leipzig, Leipzig, Germany. ${ }^{6}$ Institute of Medical Microbiology and Epidemiology of Infectious diseases, Faculty of Medicine, University of Leipzig, Leipzig, Germany. ${ }^{7}$ Fraunhofer Institute for Cell Therapy and Immunology, Leipzig, Germany.

\section{Authors' contributions}

BT was the primary researcher, conceived the study, designed, conducted data analysis and drafted the manuscript for publication.

$F B, A M$ and $A G$ assisted in data collection and reviewed the initial and final drafts of the manuscript.

FE and US interpreted the results, and reviewed the initial and final drafts of the manuscript.

All the authors read and approved the final manuscript for submission for publication.

\section{Competing interests}

The authors declare that they have no competing interests.

\section{Received: 21 October 2009}

Accepted: 14 January 2010 Published: 14 January 2010

\section{References}

1. Sandstrom E, Uhnoo I, Ahlqvist-Rastad J, Bratt G, Berglund T, Gisslén M, Lindbäck S, Morfeldt L, Ståhle L, Sönnerborg A, Swedish Consensus Group: Antiretroviral treatment of human immunodeficiency virus infection: Swedish recommendations. Scand J Infect Dis 2003, 35:155-167.

2. UNAIDS/WHO: AIDS Epidemic Update December 2005. Geneva 2005, 234-240.

3. UNAIDS and World Health Organization: AIDS epidemic update. 2003, 123-129.

4. Murphy EL, Collier AC, Kalish LA, Assmann SF, Para MF, Flanigan TP, Kumar PN, Mintz L, Wallach FR, Nemo GJ, Viral Activation Transfusion Study Investigators: Highly active antiretroviral therapy decreases mortality and morbidity in patients with advanced HIV disease. Ann Intern Med 2001, 135:17-26.

5. Mocroft A, Ledergerber B, Katlama C, Kirk O, Reiss P, d'Arminio Monforte A, Knysz B, Dietrich M, Phillips AN, Lundgren JD, EuroSIDA study group: 
Decline in the AIDS and death rates in the Euro SIDA study: an observational study. Lancet 2003, 362:22-29.

6. Palella FJ Jr, Delaney KM, Moorman AC, Loveless MO, Fuhrer J, Satten GA, Aschman DJ, Holmberg SD: Declining morbidity and mortality among patients with advanced human immunodeficiency virus infection. $N$ Engl J Med 1998, 338:853-860

7. Egger M, Hirschel B, Francioli P, Sudre P, Wirz M, Flepp M, Rickenbach M, Malinverni R, Vernazza P, Battegay M: Impact of new antiretroviral combination therapies in HIV infected patients in Switzerland: prospective multicentre study. Swiss HIV Cohort Study. Bmj 1997, 315:1194-1199.

8. Furtado MR, Callaway DS, Phair JP, Kunstman KJ, Stanton JL, Macken CA, Perelson AS, Wolinsky SM: Persistence of HIV-1 transcription in peripheralblood mononuclear cells in patients receiving potent antiretroviral therapy. N Engl J Med 1999, 340:1614-1622.

9. Dornadula $G$, Zhang H, VanUitert B, Stern J, Livornese L Jr, Ingerman MJ, Witek J, Kedanis RJ, Natkin J, DeSimone J, Pomerantz RJ: Residual HIV-1 RNA in blood plasma of patients taking suppressive highly active antiretroviral therapy. Jama 1999, 282:1627-1632.

10. Ledergerber B, Egger M, Opravil M, Telenti A, Hirschel B, Battegay M, Vernazza P, Sudre P, Flepp M, Furrer H, Francioli P, Weber R: Clinical progression and virological failure on highly active antiretroviral therapy in HIV-1 patients: a prospective cohort study. Swiss HIV Cohort Study. Lancet 1999, 353:863-868.

11. Paredes R, Mocroft A, Kirk O, Lazzarin A, Barton SE, van Lunzen J, Katzenstein TL, Antunes F, Lundgren JD, Clotet B: Predictors of virological success and ensuing failure in HIV-positive patients starting highly active antiretroviral therapy in Europe: results from the Euro SIDA study. Arch Intern Med 2000, 160:1123-1132.

12. Coffin JM: HIV population dynamics in vivo: implications for genetic variation, pathogenesis, and therapy. Science 1995, 267:483-489.

13. Perelson AS, Neumann AU, Markowitz M, Leonard JM, Ho DD: HIV-1 dynamics in vivo: virion clearance rate, infected cell life-span, and viral generation time. Science 1996, 271:1582-1586.

14. Sethi AK, Celentano DD, Gange SJ, Moore RD, Gallant JE: Association between adherence to antiretroviral therapy and human immunodeficiency virus drug resistance. Clin Infect Dis 2003, 15:1112-1118.

15. Poppa A, Davidson O, Deutsch J, Godfrey D, Fisher M, Head S, Horne R, Sherr L, British HIV Association (BHIVA); British Association for Sexual Health and HIV (BASHH): Guidelines on provision of adherence support in individuals receiving ART. 2005, 2:12-19.

16. Ethiopian Ministry of Health: Ethiopian monthly antiretroviral treatment report. Addis Ababa (Ethiopia): Ministry of Health 2008.

17. Paterson DL, Swindells S, Mohr J, Brester M, Vergis EN, Squier C, Wagener MM, Singh N: Adherence to protease inhibitor therapy and outcomes in patients with HIV infection. Ann Intern Med 2000, 133:21-30.

18. Bangsberg DR, Hecht FM, Charlebois ED, Zolopa AR, Holodniy M, Sheiner L, Bamberger JD, Chesney MA, Moss A: Adherence to protease inhibitors, HIV-1 viral load, and development of drug resistance in an indigent population. AIDS 2000, 14:357-366.

19. Sodergard B: Adherance and readiness to antiretroviral treatment. Acta Universities Upsalinesis. PhD thesis 2006.

20. Gold RS, Hinchy J, Batrouney CG: The reasoning behind decisions not to take up antiretroviral therapy in Australians infected with HIV. Int J STD AIDS 2000, 113:61-70.

21. Machtinger EL, Bangsberg DR: Adherence to HIV Antiretroviral therapy. HIV In sit 2006, 7:16-22.

22. Tadios Y, Davey G: Retroviral drug adherence \& its correlates in Addis Ababa, Ethiopia. Ethiop Med J 2006, 44:237-244.

23. Mengesha A, Worku A: Assessment of antiretroviral treatment among HIV infected persons in the Ministry of Defense Hospitals. AAU; MPH Thesis 2005.

24. Gordillo V, del Amo J, Soriano V, Gonzalez-Lahoz J: Socio demographic and psychological variables influencing adherence to antiretroviral therapy. PMED AIDS 1999, 13:1763-9.

25. Gifford AL, Borman J E, Shively MJ, Wright BC, Richman DD, Bozzette SA: Predictors of self-reported adherence and plasma HIV concentrations in patients on multi drug antiretroviral regimens. JAIDS 2000, 23:386-95.
26. Bonolo PDF, Casar CC, Acurio FA, et al: Non-adherence among patients initiating antiretroviral therapy: a challenge for health professionals in Brazil. JAIDS 2006, 19:5-13.

27. Laurent C, Fatou N, Gueye $N$, et al: Long-term follow up of a cohort of patients on HAART in Senegal (abstract). 10th Conference on Retroviruses \& Opportunistic Infections, Boston 2003.

28. Willey C, Redding C, Stafford J, Garfield F, Geletko S, Flanigan T, Melbourne K, Mitty J, Caro JJ: Stages of change for adherence with medication regimens for chronic disease: development and validation of a measure. Clin Ther 2000, 22:858-71.

29. Singh N, Squier C, Sivek M, Wagener M, Nguyen H, Yu VL: Determinants of compliance with HAART therapy in patients with human immunodeficiency virus: prospective assessment with implications for enhancing compliance. AIDS 1996, 8:261-269.

30. Pratt R, Robinson N, Loveday HP, Pellowe CM, Franks PJ: Improvement in sexual drive and a falling viral load are associated with adherence to HAART therapy. 12th World AIDS Conference, Geneva Abstract 323431998.

31. Catz S, Heckman T, Kochman A: Adherence to HAART therapy among older adults living with HIV disease. 4th International Conference on the Biophysical Aspects of HIV Infection, Canada Ottawa 1999, Poster 18.

32. Buhrich N, Judd FK: HIV and psychiatric disorders. Managing HIV Sydney: Australasian Medical Publishing CompanyStewart G 1997.

33. Hayman J, Buhrich N: Psychiatric aspects. The AIDS Manual Sydney: Maclennon \& PettyGold J, Penny R, Ross M, Morey S, Stewart G, Donovan B, Berenger S 1994

34. Wright EJ, Brew BJ, Nurrie JN, MCArthur JC: HIV-induced neurological disease. Managing HIV Sydney: Australasian Medical Publishing CompanyStewart G 1997 .

35. Holzemer WL, Corless IB, Nokes KM, Turner JG, Brown MA, Powell-Cope GM, Inouye J, Henry SB, Nicholas PK, Portillo CJ: Predictors of self-reported adherence in persons living with HIV disease. AIDS Patient Care and STDS 1999, 13:185-197.

36. Maisels L, Steinberg J, Tobias C: An investigation of why eligible patients do not receive HAART. AIDS Pat Care STDS 2001, 15:185-91.

37. Mannheimer SB, Matts J, Telzak E, Chesney M, Child C, Wu AW, Friedland G: Quality of life in HIV-infected individuals receiving antiretroviral therapy is related to adherence. AIDS Care 2005, 17:10-22.

38. Wagner G, Miller LG: Is the influence of social desirability on patients' self-reported adherence overrated? J Acquir Immune Defic Syndr 2004, 35:203-204

doi:10.1186/1742-6405-7-2

Cite this article as: Tessema et al:: Magnitude and determinants of nonadherence and nonreadiness to highly active antiretroviral therapy among people living with HIV/AIDS in Northwest Ethiopia: a cross sectional study. AIDS Research and Therapy 2010 7:2.

\section{Submit your next manuscript to BioMed Central and take full advantage of:}

- Convenient online submission

- Thorough peer review

- No space constraints or color figure charges

- Immediate publication on acceptance

- Inclusion in PubMed, CAS, Scopus and Google Scholar

- Research which is freely available for redistribution

Submit your manuscript at www.biomedcentral.com/submit
C Biomed Central 